\title{
Designing an Elderly Day Care Business Model in Bandar Lampung
}

\author{
Sarah Angela Manik ${ }^{* 1}$, Annisa Ramadanti ${ }^{1}$, Nimmi Zulbainarni ${ }^{1}$ \\ ${ }^{1}$ School of Business IPB University \\ "Corresponding author. Email: sarangelmanik@gmail.com
}

\begin{abstract}
Nowadays, human life expectancy begins to increase year by year, especially in the elderly group. Therefore, the attention for the elderly deserves to be improved by paying attention to their welfare and health. Current development demands the life of the modern society in Indonesia to have a high work mobility leading to a less time to pay attention to the elderly parents. The nursing home as a place of social service is specifically intended to take care of the elderly who live there. However, there is an elderly market segment that does not want to live far from their home or family. This resulted in the emergence of an idea to design an elderly day care concept aimed at accommodating the elderly to be able to remain active outside, without living far from their family. This study used design thinking method to design the elderly day care business model in Bandar Lampung as it is presumed to be able to create solutions for the potential market segment.
\end{abstract}

Keywords-Business model, Design thinking, Elderly, Elderly day care.

\section{INTRODUCTION}

Elderly phase is part of the phases experienced by human beings. This phase is the last part of the human being lifecycle. The Law of the Republic of Indonesia No. 13 Year 1998 concerning Elderly Welfare explains that elderly are people who have reached the age of 60 years old and above.

The number of elderly in Indonesia was projected to reach approximately 63.31 million people in 2045 or nearly $20 \%$ of the population [1]. It shows that Indonesia is a country entering the aging structured population, in which there is an increase in life expectancy followed by an increase in the number of elderly with the number have exceeded $7 \%$ of the population.

One of the provinces experiencing a rising number of elderly is Lampung Province. Bandar Lampung, the capital city of Lampung Province, was projected to have $7.22 \%$ elderly in 2020 [2]. It indicates that Bandar Lampung has also entered aging structured population. This number is expected to rise continuously given a rise in life expectancy. Such increase will serve challenges when the elderly is far from being healthy.
Bandar Lampung has been categorized as metropolitan city [3]. Since the start of the transmigration program from Java to Sumatera, the citizen of Bandar Lampung comprises various ethnic groups, including the local people and migrants. Conversely, there are also many local people moving outside Lampung. Moreover, Lampung is the gate between Java and Sumatera. The urban society, including in Bandar Lampung, experiences a change in its family composition. A big family usually consisting of parents, children, and grandparents changes to main family, causing the elderly to live alone or only with their spouse. In relation with the status of living in 2019, 5.92\% of the elderly in the urban area of Lampung Province lived alone, $18.90 \%$ lived with their spouse, $36.30 \%$ lived with their family, and $37.23 \%$ lived with three generations. Although there are many elderly live with their family, there is a high possibility that they are left alone or only with their spouse by their family to work during the day, especially in the urban area. Such condition could lead the elderly to feel the loneliness or experience both physical and mental health problems [4].

In many cases, loneliness could cause a pressure on the physical and mental health as people have no friend 
to shop and eat together [5]. The lack of interaction experienced by the elderly is the major cause of their loneliness. If such condition left worse over time, it would lead to a more serious problems, like depression, that could inhibit their daily activities.

Ironically, Indonesia still has limited number of facilities provided for the elderly to keep them being active and productive. Most of the facilities provided are in the form of nursing home (panti jompo or panti werdha) where the elderly live there every day. Nursing home, in Indonesia, could give an impression that the elderly are left out. Besides, there are potential market segments whose needs are not fulfilled by the nursing home, especially the ones who do not want to leave their home or family. Therefore, there need to be a facility running or taking over the functions left out by the family and the nursing home, such as elderly day care.

In addition to helping the family to take care of the elderly [6], elderly day care is expected to be a place where the elderly could engage in many activities with their peers, including health-supporting activities, creative activities, and social activities [7]. It could be an effort to address the health issues in Sustainable Development Goals (SDGs), especially the third goal of ensuring healthy lives and promote well-being for all at all ages, including the elderly.

Bandar Lampung, as one of the metropolitan cities in Indonesia, is believed to have the potential market segment for elderly day care. Hence, this study aimed to: 1) identify the needs of the elderly in Bandar Lampung; 2) design the products according to the needs of the elderly in Bandar Lampung; 3) designing an elderly day care business model in Bandar Lampung.

This study focused on designing an elderly day care business model in Bandar Lampung using design thinking method which includes the use of Business Model Canvas (BMC). The elderly in this study refer to the ones aged 60 years old and above according to the Law No. 13 Year 1998.

\subsection{Elderly Day Care}

According to the Regulation of the Minister of Social Affairs No. 19 Year 2012 concerning Elderly Social Service Guidelines, elderly social services are efforts aimed to help the elderly in restoring and improving their social function. One of the elderly social service programs is day care services. Day care is a social service model provided for the elderly that is held during the day, indoor and/or outdoor, at specific time of maximum 12 hours (without stay over), and managed by the government or society/private party.

Elderly day care is different with nursing home (panti jompo) that is more common as a place for the elderly in Indonesia. Nursing home is established to provide social services for the left-out elderly so that they could live well in society, consisting of physical, spiritual, social, and psychological care, protection, and development [8]. Purwoko and Wibowo [9] explained the differences between nursing home and elderly day care (Table 1).

Table 1. Differences between nursing home and elderly day care

\begin{tabular}{|l|l|l|}
\hline Classification & Nursing home & Elderly day care \\
\hline Service hours & 24 hours & $10-12$ hours \\
\hline $\begin{array}{l}\text { Characteristics } \\
\text { of elderly }\end{array}$ & $\begin{array}{l}\text { Tend to be } \\
\text { neglected }\end{array}$ & $\begin{array}{l}\text { Still taken care by } \\
\text { their family }\end{array}$ \\
\hline Institution & Mostly government & Private \\
\hline Facilities & $\begin{array}{l}\text { Daily needs } \\
\text { fulfillment }\end{array}$ & $\begin{array}{l}\text { According to } \\
\text { customer } \\
\text { expectation; } \\
\text { enjoyable activities } \\
\text { for the elderly }\end{array}$ \\
\hline Costs & $\begin{array}{l}\text { Free or cheaper or } \\
\text { according to the } \\
\text { financial ability }\end{array}$ & $\begin{array}{l}\text { More expensive than } \\
\text { nursing home as it } \\
\text { offers value(s) }\end{array}$ \\
\hline
\end{tabular}

\subsection{Design Thinking}

Design thinking adopts a designer's way of thinking in solving problems [10]. It is a method to create values by matching human needs, technology, and business system [11]. It is well known for its comprehensive thinking process to create solutions started from empathy process (human-centred) to continuous innovation based on user needs [12].

There are five steps of design thinking, namely empathize, define, ideate, prototype, and test [13] Empathize means positioning ourselves into the mind of potential customers/consumers and understand them to create products that could solve their problems. Empathize is conducted by observing what they see, hear, think and feel, say and do, as well as their pain and gain (empathy map) (Osterwalder and Pigneur 2010) [14] Define refers to collecting the information obtained from empathize step and describing the discovered needs. This step aims to make a problem statement, followed up by focusing on their problems. Ideate is a design process focusing on creating ideas that might be the solutions to the discovered problems. We have understood what the potential customers/consumers need and make it as the basis for the design process. Prototype means realizing the ideas into their real forms. This prototype is tested (test step) to the potential customers/consumers by demonstrating it to them to gain their responses and make improvements.

\subsection{Business Model Canvas (BMC)}

BMC is a tool, in the form of one-page canvas comprising nine building blocks, used to visualize, describe, evaluate, and create business model [14]. The nine building blocks of BMC are customer segments, value propositions, channels, customer relationships, 
revenue streams, key resources, key activities, key partnerships, and cost structure.

\section{METHODS}

\subsection{Location and Time}

This study was carried out in Bandar Lampung, Lampung Province, from March to June 2020. Bandar Lampung was chosen as it is the capital city of Lampung Province and one of the metropolitan cities in Indonesia.

\subsection{Type of Study}

This study was a qualitative study using phenomenology approach. According to [15], qualitative study highly depends on the information from the objects or participants in a broad scope, uses general questions and data collection that mostly consists of statements from the participants, as well as describes and analyzes the statements. Phenomenology attempts to explain the meaning of people's life experiences concerning a concept or symptoms, including self-concept or their own view of life [15]. This approach was used to understand the life of the elderly.

\subsection{Sampling Method}

Snowball sampling method applied in this study to acquire small number of samples (respondents) at the beginning which then becomes large by requesting the initially acquired sample to select his/her friends to become respondents [16]. The ten respondents acquired were considered sufficient, according to Dukes in Creswell [15] who recommended to use three to ten samples in phenomenology study. The criteria of respondents in this study were elderly aged 60 years old and above, tend to lack of activities inside and outside home, and were living in Bandar Lampung separately from their family or with their family but were left to work during the day.

\subsection{Research Stages}

The stages of this study refer to the five stages of design thinking method as follows.

1. Empathize

In this stage, the researcher conducted in-depth interview on the respondents to identify and understand the problems and needs of the elderly. The obtained information were mapped into the empathy map as an analytical tool.

2. Define

The needs of the elderly identified from the empathize stage were analyzed to design the products in line with their needs. The analysis was undertaken by listing the problems of the respondents into table to facilitate solution finding process in the next stage.
3. Ideate

In this stage, ideas of solutions were created through brainstorming and discussion with knowledgeable partners. The aspirations were collected and made into business model using BMC.

4. Prototype

Prototype is an example or initial model of products Prototype is the real form of the abstract ideas. The design of products based on the ideas created in ideate stage. The prototype would be used to test whether the products designed could solve the users' problems.

5. Test

The formed prototype was tested on the respondents by explaining the prototype through presentation and reinterviewing the respondents. The test was conducted to gain feedbacks beneficial for making improvements on the prototype according to the user expectation.

\section{RESULTS}

Being old is not a disease, but a process of diminishing body endurance in facing internal and external stimuli. The elderly will certainly experience changes over time. However, they could be healthy if their basic needs are fulfilled. The hierarchy of human basic needs consists of physiological needs, safety needs, love and belonging needs, esteem needs, and selfactualization [17].

The elderly who lack of those needs would look for a facility that could accommodate their needs. Elderly day care is an alternative facility other than nursing home. However, in Indonesia including Bandar Lampung, elderly day care concept has not been developed. Thus, designing its business model, from empathize stage to test stage, was deemed important.

\subsection{Empathize}

This stage utilized an empathy map (Figure 1). In terms of what respondents think and feel, they tended to feel bored as they do not know what to do after completing house chores. They felt anxious if they were alone at home. They complained about their declining health due to the lack of movement. They want to stay healthy so that they would not trouble their family. The ones living far away from their family felt the willingness to meet and share with people, be given attention, and enjoy their life.

In terms of what they say and do, they tended to have few things to do at home, like doing house chores and relaxing. The ones who know about internet usually open social media for entertainment. Some elderly who do not feel at home would visit their neighbors to simply ask about their condition. Some elderly said if they still have a chance to work, they would be willing to accept the offer to be productive as long as they are able and strong. 
The respondents saw that their home was quiet because their children were busy working or they live separately with their children. They tended to meet the same people every day, leading them to boredom. As many people were attached to their smartphone, the elderly saw that people around them were busy on their own. They also saw that their age group were frequently made as an object of crime by people who took advantage of their weaknesses.

The respondents usually heard that the elderly who stay at home with only few activities are easily get sick and have stiff joints. Therefore, they are frequently considered weak and understandable. In fact, there are many things that can be performed by healthy elderly. Besides, they heard that elderly group tend to return to their childhood nature, such as want to be spoiled and heard. Some respondents also heard unfavorable assumption about nursing home that the children do not take care of their elderly parents.

The pains of the respondents were as follows: 1) they often got offended, due to their high sensitivity, when their words were not accepted by others, which can lead to a quarrel; 2) they found it hard to look for a help when they need it especially when their family were not close; 3 ) they spaced out much due to the lack of activities; 4) they were afraid to bother or become a burden to their family.

The gains expected by the respondents were as follows: 1) they could gather with peers to share stories as they wanted noisy and lively atmosphere; 2) they can do their hobbies in their leisure time; 3) they could be beneficial for others and share their stories and achievements in life; 4) they could have a good quality of life; 5) they could enjoy life after working hard when they were young.

\subsection{Define}

The problems faced by the respondents, according to the empathize stage, were defined in this stage by categorizing and listing the problems into Table 2 .

Table 2. Differences between nursing home and elderly day care

\begin{tabular}{|l|l|}
\hline Code & Problem categories \\
\hline A & Boredom with their routines \\
\hline P1 & $\begin{array}{l}\text { They did not know what to do after completing } \\
\text { the house chores }\end{array}$ \\
\hline P2 & They slept too much \\
\hline P3 & They often spaced out \\
\hline B & Loneliness \\
\hline P4 & They had view friends to talk and share hobbies \\
\hline P5 & They tended to meet the same people every day \\
\hline P6 & They needed attention \\
\hline P7 & They found it hard to look for help \\
\hline P8 & They need recreation and entertainment \\
\hline C & Health problems \\
\hline M9 & Stiff body \\
\hline
\end{tabular}

\begin{tabular}{|l|l|}
\hline M10 & Headache \\
\hline M11 & They easily complained (on health) \\
\hline D & Anxiety \\
\hline M12 & They were prone to crime \\
\hline
\end{tabular}

\subsection{Ideate}

Based on the problems defined in the define stage, ideas of solutions to the problems were explored through brainstorming and put into the BMC (Figure 2). The ideas of solutions generated in this stage were the three types of programs possibly offered by the elderly day care, namely routine programs, special programs, and additional programs.

1. Routine programs are the programs that will be certainly conducted by time (daily and non-daily). Daily programs are conducted from morning to evening, including morning exercise, rest, entertainment activities (watching film/video, playing, sharing, and talk show), lunch, and going home. Non-daily routine programs are routine health check-up conducted once/twice a month, refreshing activity by going outside, such as to the tourism objects, twice a year, and hangout.

2. Special programs are optional for the elderly, consisting of seminar on health, psychological consultation, and activity classes (knitting/embroidering, drawing and painting, singing, playing music, dancing, training, etc.).

3. Additional programs are carried out on demand, namely birthday celebration and wedding anniversary celebration.

\subsection{Prototype}

The designed prototypes were in the form of program schedule at the elderly day care (Table 3) and the elderly day care's 3D building-design (Figure 3). The designed program schedule was as follows.

Table 3. The designed program schedules

\begin{tabular}{|c|c|c|}
\hline Program & Time (WIB) & Activities \\
\hline \multirow[t]{2}{*}{ Routine } & $07.30-08.00$ & $\begin{array}{l}\text { Morning exercise, yoga, } \\
\text { walking, therapy }\end{array}$ \\
\hline & $08.00-09.00$ & Rest \\
\hline \multirow{2}{*}{ Special } & $09.00-10.00$ & Seminar \\
\hline & $10.00-11.00$ & Consultation \\
\hline Routine & $11.15-12.00$ & $\begin{array}{ll}\text { Gather in the hall } \\
\text { - } & \text { Watching } \\
\text { - } & \text { Entertainment } \\
\text { - } & \text { Playing games } \\
\text { - } & \text { Sharing } \\
\text { - } & \text { Talk show } \\
\end{array}$ \\
\hline Routine & $12.00-13.00$ & Praying \\
\hline Routine & $13.00-13.30$ & Lunch \\
\hline Special & $14.00-16.00$ & $\begin{array}{l}\text { Nap } \\
\text { Activity class: } \\
\text { Knitting/embroidering, } \\
\text { drawing and painting, } \\
\text { singing, dancing, playing } \\
\text { music, training, etc. }\end{array}$ \\
\hline
\end{tabular}




\begin{tabular}{|l|l|l|}
\hline Routine & $16.00-17.00$ & $\begin{array}{l}\text { Going home (picked up or } \\
\text { shuttle service) }\end{array}$ \\
\hline \multirow{4}{*}{ Routine } & Once/twice a month & Health check-up \\
\cline { 2 - 3 } & Twice a year & $\begin{array}{l}\text { Refreshing to the tourism } \\
\text { objects }\end{array}$ \\
\cline { 2 - 3 } & Once a month & $\begin{array}{l}\text { Going outside for karaoke, } \\
\text { lunch, etc. }\end{array}$ \\
\cline { 2 - 3 } Additional & Big days & $\begin{array}{l}\text { Special events } \\
\text { Birthday and wedding } \\
\text { anniversary celebration }\end{array}$ \\
\hline
\end{tabular}

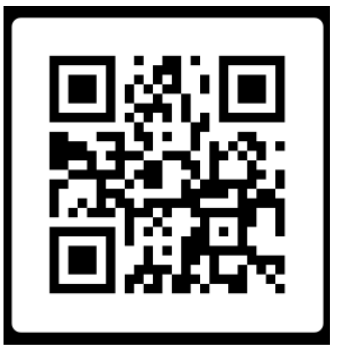

Figure 3 Video of 3D building-design

In terms of the building design, the designed facilities were lobby, office, bedrooms, toilet, dining room, kitchen, medical room, activity rooms, room for watching, hall, and outdoor facilities. The building for elderly was considered better to have a healthy, natural, and green concept, embodied through the green front yard and back yard filled with plants for gardening activity. The yard was also designed with a fish pond and relaxing area. The lobby was designed to be warm, peaceful, and friendly to greet the elderly. The bedrooms were classified into VIP bedroom (for one person) and master bedroom (collective use). The floor was equipped with carpet to avoid slip.

\subsection{Test}

1. The suitability of products with the existing problems (Table 4)

Table 4. Problem and solution suitability

\begin{tabular}{|l|l|}
\hline Problems & Solutions \\
\hline Boredom & $\begin{array}{l}\text { Creating elderly day care to be joined } \\
\text { by the elderly }\end{array}$ \\
\hline Loneliness & $\begin{array}{l}\text { Forming communities with the elderly } \\
\text { as the members }\end{array}$ \\
\hline Health problems & $\begin{array}{l}\text { Having a medical room and routine } \\
\text { health check-up }\end{array}$ \\
\hline Anxiety & $\begin{array}{l}\text { Offering consultation service to share } \\
\text { stories and relieve their burden }\end{array}$ \\
\hline Lack of activities & $\begin{array}{l}\text { Offering various activities that can be } \\
\text { chosen by the elderly }\end{array}$ \\
\hline Sensitivity & $\begin{array}{l}\text { Offering caregiving service by } \\
\text { professional caregivers }\end{array}$ \\
\hline $\begin{array}{l}\text { Assumptions on } \\
\text { nursing home }\end{array}$ & $\begin{array}{l}\text { Offering visually attractive building } \\
\text { that is different from the common } \\
\text { nursing home }\end{array}$ \\
\hline
\end{tabular}

2. The interest of respondents on the elderly day care business model
The interest of respondents on the elderly day care business model was reflected on their statements as follows:

- They have not found any services like elderly day care.

- They want to try if the programs become real.

- They believe that elderly day care business model would be loved if it is promoted well.

- These programs can remove their boredom

- Elderly day care business model could be a preventive effort for health and make them productive.

- The building design is attractive and lively.

In addition, the attractive services according to the respondents were shuttle service and talk show featuring cool speakers.

3. The willingness to pay of the respondents

Payment was classified into four choices, namely payment per services, per day, per month, and per year. Most of the respondents chose monthly payment $(60 \%)$ and were willing to pay Rp2 million-5 million per month $(40 \%)$ according to the selected services. The estimated cost breakdown was as follows:

- Activity: Rp100 000/activity

- Lunch: Rp 40000

The price paid by the customers would depend on the selected facilities offered as follows:

- Silver package: Activity class

- Gold package: Activity class, lunch, evening snack, and master bedroom

- Platinum package: Activity class, lunch, evening snack, VIP bedroom, and shuttle service

4. Feedbacks from the respondents

- The elderly who stay active in social environment and feel needed by their family and local society would feel content and happy.

- This business model would be better if it has lodging service when needed as there was an experience of being left alone when the family were out of town.

- The communities in elderly day care could provide profits for the elderly through creative entrepreneurship, such as crafts.

- When entering the elderly age, the elderly would love to share stories. They feel happy when they are heard and complimented.

The feedbacks had been accommodated in the prototype to complete the elderly day care business model.

\section{DISCUSSION}

The solution proposed for the problems experienced by the respondents was by designing a day care with various facilities that could support their physical, psychological, and spiritual needs. The day car was aimed for the elderly who need attention, services, and a place to socialize and do activities with peers. 
Based on the BMC of the elderly day care (Figure 2), the value propositions were according to the expectations of the potential customers. In terms of key resources, the required human resources were professional caregivers, security officer, activity coaches, and internal staffs. The required physical resources were elderly day care building, information technology (IT) equipment, other equipment, and shuttle transport. Patent, partnership, and customer data were intellectual resources needed. In terms of cost structures, the fixed costs comprised salaries, cost of the building, IT equipment, and interior goods. Meanwhile, the variable costs covered electricity and water utility, fuel, materials for kitchen, supporting materials for activities, promotion, and training.

\section{CONCLUSION}

The elderly day care business model is an alternative solution that could be harnessed by the elderly's family or the elderly themselves in fulfilling their basic needs. The respondents were satisfied with the prototype as it was in line with the brainstorming process and it could solve their problems. They only suggested to provide the selling of elderly's equipment and the addition of outdoor activities.

\section{REFERENCES}

[1] [1] Statistics Indonesia, Statistics of Elderly Citizen 2018. Statistik Penduduk Lanjut Usia 2018. Jakarta, ID: Statistics Indonesia, 2018.

[2] Statistics Indonesia, Projection of Lampung Province's District/City Citizen 2010-2020. Proyeksi Penduduk Kabupaten/Kota Tahun 20102020 Provinsi Lampung. Jakarta, ID: Statistics Indonesia, 2015.

[3] Ministry of National Development Planning, Regional Medium Term Development Plan 20102015. Rencana Pembangunan Jangka Menengah Daerah 2010-2015. Bandar Lampung (ID): Ministry of National Development Planning.

[4] Ministry of Social Affairs, The Coaching Module of Elderly Social Services. Modul Pendampingan Pelayanan Sosial Lanjut Usia. Jakarta (ID): Ministry of Social Affairs.

[5] H. L. Kaplan, B. J. Sadock, and J. A. Grebb, Kaplan and Sadock's Synopsis of Psychiatry: Behavioral Sciences Clinical Psychiatry. Sinopsis Psikiatri Kaplan dan Sadock: Ilmu Pengetahuan Perilaku Psikiatri Klinis. Jakarta (ID): Bina Putra Aksara, 1997.

[6] J. Depalma, "Positive outcomes and adult day care," Home Health Care Manag. Pract., vol. 15(4), pp. 342-343, 2003.
[7] C. Bulsara, C. Etherton-Beer, and R. Saunders, "Models for community-based day care for older people: a narrative review," Cogent Social Sciences, vol. 2(1), 2016.

[8] Department of Social Affairs, Implementation Guidelines for Pilot Tresna Wredha Social Institution. Petunjuk Pelaksanaan Panti Sosial Tresna Wredha Percontohan. Jakarta (ID): Department of Social Affairs, 1997.

[9] S. V. Purwoko and M. Wibowo, "The Interior Design of Elderly Day Care Centre as an Elderly Activity Centre in Surabaya," "Perancangan Interior Elderly Day Care Centre sebagai Pusat Aktivitas Manula di Surabaya," Jurnal Intra, vol. 2(2), pp. 655-660, 2014.

[10] M. Y. MF, "Dragon fruit agrotourism business development in Batam City using design thinking manaegement approach," "Pengembangan bisnis agrowisata buah naga di Kota Batam melalui pendekatan design thinking management," Jurnal Ilmiah Manajemen UPB, vol. 5(2), pp. 51-58, 2017.

[11] T. Brown, Change by Design. New York (US): Harper Collins, 2009.

[12] A. A. Razi, I. R. Mutiaz, and P. Setiawan. "Design thinking method application on UI/UX design model on an application for handling reports of lost and scattered goods," "Penerapan metode design thinking pada model perancangan UI/UX aplikasi penanganan laporan kehilangan dan temuan barang tercecer," Demandia, vol. 3(2), pp. 75-93, September 2018.

[13] Hasso Plattner Institute of Design, An Introduction to Design Thinking: Process Guide. California (US): Hasso Plattner Institute of Design.

[14] A. Osterwalder and Y. Pigneur, Business Model Generation. New Jersey (US): John Wiley \& Sons, 2010 .

[15] J. W. Creswell and C. N. Poth, Qualitative Inquiry and Research Design. London (UK): Sage Publications, 1998.

[16] Sugiyono, Methods on Educational Research: Quantitative, Qualitative, and R\&D Approach. Metode Penelitian Pendiidkan: Pendekatan Kuantitatif, Kualitatif, dan R\&D. Bandung (ID): Alfabeta, 2014.

[17] A. Maslow, Motivation and Personality. Motivasi dan Kepribadian. Jakarta (ID): Rajawali, 2010. 


\section{APPENDIX}

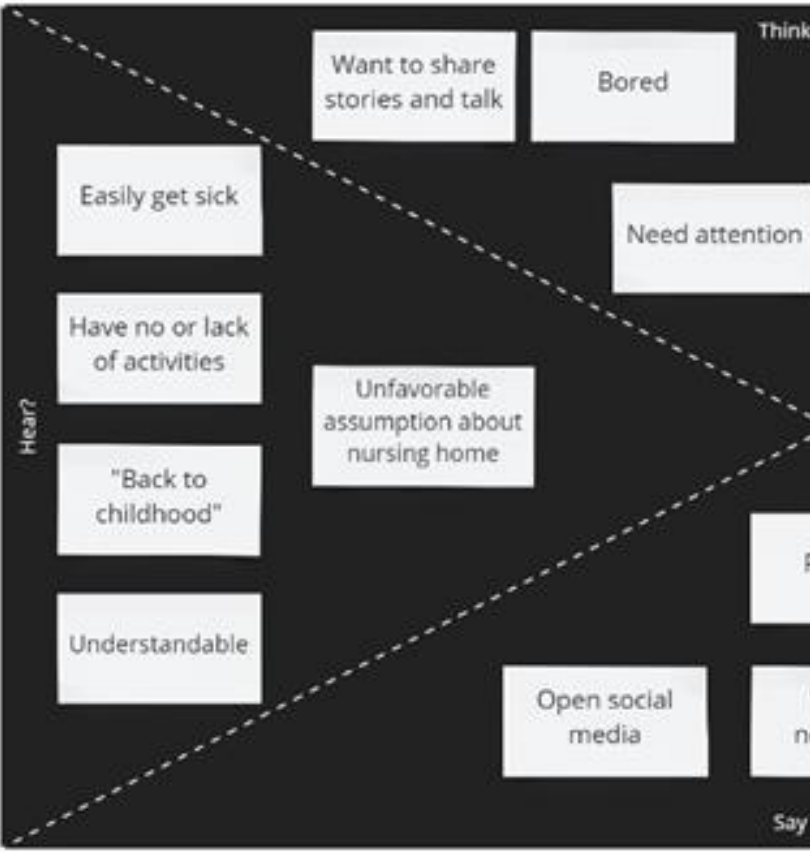

Pain

Get sensitive

and offended

Difficult to find

Afraid to

Do much

help

spacing out

Figure 1 Empathy map

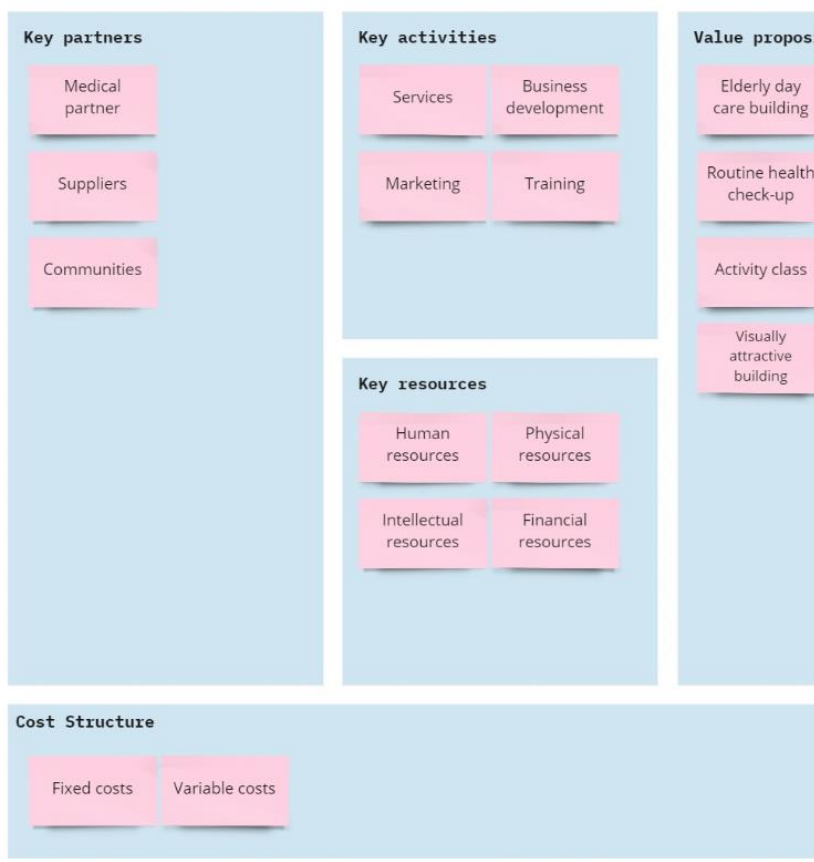

Figure 2 The elderly day care's BMC from ideate stage 